\title{
Tatalaksana Cerebral Venous Sinus Thrombosis dengan Alkoholik dan Perdarahan Intraserebral
}

\author{
Fitri Sepviyanti $\mathbf{S}^{*}$, Rose Mafiana ${ }^{* *}$, Eri Surahman***) \\ ${ }^{*}$ Departemen Anestesiologi dan Terapi Intensif Nobel Medical Collage Teaching Hospital, ${ }^{* *}$ Departemen \\ Anestesiologi \& Terapi Intensif Fakultas Kedokteran Universitas Sriwijaya-Rumah Sakit M. Hoesin Palembang, \\ ${ }^{* * *}$ Departemen Anestesiologi \& Terapi Intensif Fakultas Kedokteran Universitas Padjadjaran-RSUP. Dr. Hasan \\ Sadikin Bandung
}

\begin{abstract}
Abstrak
Cerebral venous sinus thrombosis (CVST) adalah suatu sindrom seperti stroke, angka kejadiannya sangat jarang, sehingga dapat menjadi dilema bagi dokter di instalasi gawat darurat dalam menegakkan diagnosis. Seorang lelaki 25 tahun, $50 \mathrm{~kg}$, tinggi badan $165 \mathrm{~cm}$, mengeluh lemah anggota badan sebelah kanan sejak 12 jam sebelum masuk rumah sakit. Keluhan disertai dengan sukar berbicara. Satu hari sebelum masuk rumah sakit, pasien mabuk-mabukan dan mengalami muntah-muntah $\pm 3-5 \mathrm{x}$ /hari. Riwayat kejang, konsumsi obat-obatan dan trauma sebelumnya disangkal. Tidak ada riwayat demam, hipertensi, diabetes mellitus dan penyakit penyerta lainnya. Dilakukan dekompresi evakuasi perdarahan sebagai tindakan penyelamatan jiwa setelah pasien terehidrasi, operasi dilakukan dalam anestesi umum. Lama operasi selama 2 jam dan lama pasien teranestesi 2 jam 15 menit. Pasien dirawat di ICU selama 2 hari, lalu dipindahkan ke ruang HCU. Pada hari ke-5 pascabedah mulai diberikan enoxaparin sodium $50 \mathrm{mg}$ subcutan selama 6 hari. Lalu pasien dipindahkan ke ruang rawat inap dan pulang ke rumah pada hari ke-15 perawatan. Target pencapaian utama pada pasien CVST adalah untuk rekanalisasi penyumbatan, menjaga venous return, mengurangi risiko hipertensi vena, infark serebral dan emboli paru. Algoritma tatalaksana pasien CVST terkadang harus disesuaikan dengan kondisi klinis pasien saat tiba di rumah sakit. Pemberian low-weightmoleculer heparin (LWMH) tetap diberikan selama tidak terjadi peningkatan tekanan darah yang bermakna.
\end{abstract}

Kata kunci: alkoholik, CVST, dekompresi evakuasi perdarahan, LWMH

JNI 2018;7 (1): 44-53

\section{Cerebral Venous Sinus Thrombosis Management with Alkoholic and Intracerebral Hemorrhage}

\begin{abstract}
Cerebral venous sinus thrombosis (CVST) is a syndrome similar a stroke, the incidence is very rare, so it can be a dilemma for doctors at emergency departments to make the diagnosis. A 25 year old male weighing $50 \mathrm{~kg}$ and height $165 \mathrm{~cm}$. Patients complained of right limb wekness since 12 hours before admission. Complaints are accompanied by difficulty speaking. One day before entering the hospital, the patient got drunk and experienced vomiting \pm 3-5 times a day. History of seizures, previous consumption of drugs and trauma was denied. No history of fever, hypertension, diabetes mellitus and other comorbidities. Decompression by hematoma evacuation was performed as a life-saving action after the patient was hydrated, surgery was performed under general anesthesia. Operation duration was 2 hours and anesthesia duration was 2 hours 15 minutes. The patient was admitted to the ICU for 2 days, then transferred to the HCU room. On the $5^{\text {th }}$ day post-surgery patient got $50 \mathrm{mg}$ subcutaneous enoxaparin for 6 days. Then the patient was transferred to the ward and returned home on the 15 th day of treatment. The main achievement targets in CVST patients were for clotting recanalization, maintaining venous return, reducing the risk of venous hypertension, cerebral infarction and pulmonary embolism. The CVST patient management algorithm sometimes has to be adjusted to the patient's clinical condition upon arrival at the hospital. Provision of LWMH is still given as long as the blood pressure does not increase significantly.
\end{abstract}

Key words: alcoholic,CVST, decompressive evacuation hematoma, LWMH

JNI 2018;7 (1): 44-53 


\section{Pendahuluan}

Cerebral venous sinus thrombosis (CVST) adalah kelainan pembuluh darah otak yang jarang dan mempunyai gejala klinis yang sangat bervariasi. ${ }^{1}$ Terjadi pada $0,5 \%-3 \%$ dari seluruh kasus stroke, dengan angka kejadian sekitar 0,00035\%, terutama mempengaruhi orang muda dan anakanak tertentu sekitar $0,0007 \% .{ }^{2}$ Infark perdarahan tampak pada $40 \%$ pasien yang menjalani CTscan dan transformasi perdarahan kadangkadang menyebabkan perdarahan intraserebral atau perdarahan subarachnoid (subarachnoid hemorrhage/SAH $){ }^{4}$ namun $\mathrm{SAH}$ adalah presentasi klinis yang jarang terjadi. Keragaman manifestasi klinis meningkatkan kesulitan diagnosis CVST dan menyebabkan tatalaksana yang buruk pada pasien CVST dengan SAH akut. Hal ini disebabkan karena kurangnya penelitian tentang hubungan antara SAH akut dengan CVST di masa lalu. ${ }^{5-6}$ Sampai sekarang, hanya penelitian yang dipublikasikan tahun 2016 yang melaporkan 22 pasien CVST dengan $\mathrm{SAH}$, di mana mereka mengevaluasi kejadian dan karakteristik radiologis SAH terkait CVST. ${ }^{7}$ Penelitian retrospektif lanjutan yang dilakukan telah dipublikasikan tahun 2017 melibatkan 11 pasien CVST dengan SAH akut dari bulan Maret 2008 sampai Maret 2015 mengenai gejala klinis yang sesuai karakteristik, strategi terapi dan prognosis. $^{8}$

Pecandu alkohol cenderung mengalami gangguan pembuluh darah otak. Hubungan antara pengaruh alkohol dengan stroke belum diketahui secara pasti. ${ }^{9}$ Gejala seperti sakit kepala, mual dan mengantuk setelah minum minuman keras biasanya disebabkan oleh veisalgia. ${ }^{10}$ Diagnosis CVST mungkin terlewatkan dalam kasus seperti itu karena gejala yang tidak spesifik, kecuali seorang dokter mempunyai kecurigaan yang tinggi dan pengalaman akan hal ini. Peranan CT-scan sangat penting dalam diagnosis awal CVST dan membantu mencegah komplikasi neurologis lebih lanjut. Oleh karena itu, sangatlah penting untuk dilakukan pemeriksaan CT-scan pada pasien-pasien yang mengalami penurunan kesadaran atau kelainan neurologis lain setelah mabuk. ${ }^{9-10}$ Heparin adalah terapi andalan untuk CVST dan direkomendasikan oleh pedoman internasional. Rekomendasi ini didasarkan pada data dua penelitian secara acak dalam skala kecil. Pasien yang diterapi dengan heparin memiliki hasil klinis yang lebih baik, walaupun perbedaannya tidak signifikan secara statistik dalam meta-analisis (risiko kematian relatif $0,33,95 \%$ CI $0,08-1,21) .{ }^{11}$ Hal terpenting, tidak ada hubungan antara pemberian heparin dengan komplikasi perdarahan, yang merupakan kontraindikasi antikoagulan. Sebuah penelitian menunjukkan justru pasien yang diberi heparin dibandingkan dengan plasebo, tidak terjadi emboli paru, yang merupakan penyebab utama kematian pada pasien dengan CVST. ${ }^{11-12}$ Biasanya heparin dengan berat molekul rendah/ low-weight-moleculer heparin (LWMH) yang digunakan sebagai terapi, karena pertimbangan faktor keamanan, lebih sering digunakan dalam tatalaksana konservatif daripada heparin yang tidak terfragmentasi, kecuali pada pasien yang dilakukan tindakan neurointervensi. ${ }^{13}$

\section{Kasus}

\section{Anamnesis}

Seorang lelaki 25 tahun dengan diagnosis cerebral venous sinus thrombosis haemorrhagic conversion, berat badan $50 \mathrm{Kg}$ dan tinggi badan $167 \mathrm{~cm}$ datang ke Nobel Medical Collage and Teaching Hospital. Pasien mengeluh lemah anggota badan sebelah kanan sejak 12 jam sebelum masuk rumah sakit. Keluhan disertai dengan sukar berbicara dan menjadi rero. Satu hari sebelum masuk rumah sakit, pasien mabukmabukan dan mengalami muntah-muntah $\pm 3-5$ kali/hari. Riwayat kejang, konsumsi obat-obatan dan trauma sebelumnya disangkal. Tidak ada riwayat demam, hipertensi, diabetes mellitus dan penyakit penyerta lainnya.

\section{Pemeriksaan Fisik}

Pada pemeriksaan fisik ditemukan keadaan pasien: glassglow coma scale (GCS) 9-10 (E3V2M4-5), pupil bulat isokor, reflex cahaya $+/+$, hemiparesis anggota badan kanan motorik $4 / 5$, tekanan darah 123/78 $\mathrm{mmHg}$, laju nadi 109 $\mathrm{x} /$ menit, laju napas $20-22 \mathrm{x} /$ menit, suhu $36,5^{\circ} \mathrm{C}$. Pemeriksaan fisik lain dalam batas normal. 


\section{Pemeriksaan Penunjang}

Pemeriksaan laboratorium darah menunjukkan $\mathrm{Hb}$ 12,9 g/dL; Ht 41,2 \%; Leukosit 10300 / $\mu \mathrm{L}$; Trombosit $210 \mathrm{ribu} / \mu \mathrm{L}$; BUN $39 \mathrm{mg} / \mathrm{dL}$; Kreatinin 1,2 mg/dL; GDS $139 \mathrm{mg} / \mathrm{dL}$; Natrium $142 \mathrm{mmol} / \mathrm{L}$; Kalium 4,0 mmol/L; PT 13,6 detik; INR 0,76; APTT 31,9 detik; BT 3,3 menit; CT 7,3 menit; D-Dimer 0,1. Pada pemeriksaan CTscan: Transversus sinus, vein of labbe thombosis. Tampak edema lokal disertai daerah infark di sekitar perdarahan. Tampak sedikit pergeseran midline shift.

\section{Penatalaksanaan Anestesi}

Pasiendibawakekamaroperasi, pasien diposisikan head up $30^{\circ}$ dan diberi $\mathrm{O}_{2} 3 \mathrm{~L} /$ menit melalui nasal kanul, kemudian dipasang tensimeter, chest piece EKG, pulse oxymetri dan IoC. Dilakukan induksi anestesi umum dengan pasien dilakukan induksi dengan prinsip proteksi otak melalui kombinasi pemberian fentanyl $100 \mu \mathrm{g}$ titrasi, propofol 100

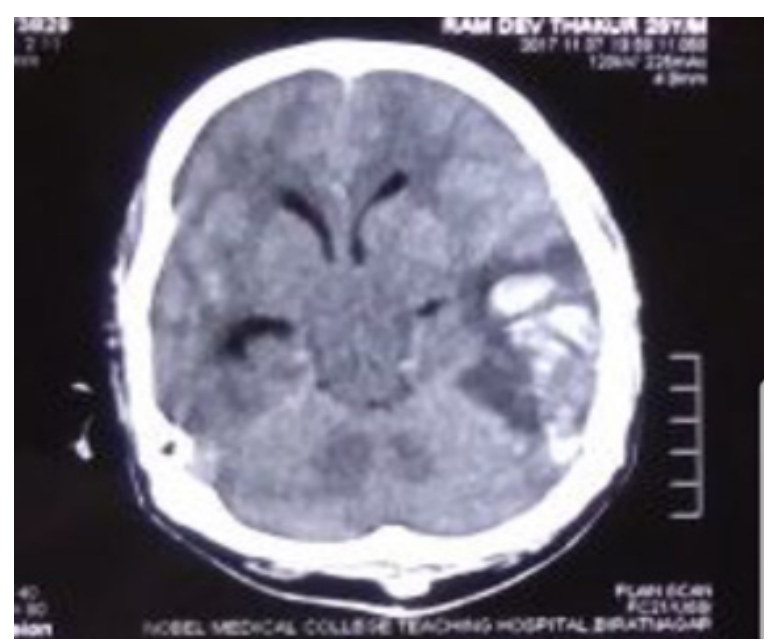

Gambar 1. Foto CT-scan Kepala

mg titrasi, vecuronium $7 \mathrm{mg}$, satu menit sebelum tindakan intubasi diberikan tambahan propofol $30 \mathrm{mg}$. Preoksigenasi selama 5 menit sebelum intubasi tanpa hiperventilasi. Intubasi sleep apneu dilakukan menggunakan laryngoscope macintosh dengan endotracheal tube (ETT) non kinking nomor 7,5, kedalaman ETT $19 \mathrm{~cm}$ pada tepi bibir. Pemeliharaan anestesi: diberikan isoflurane $0,8-1$ vol\% dengan aliran oksigen dan udara (50:50) kombinasi syringe kontinyu

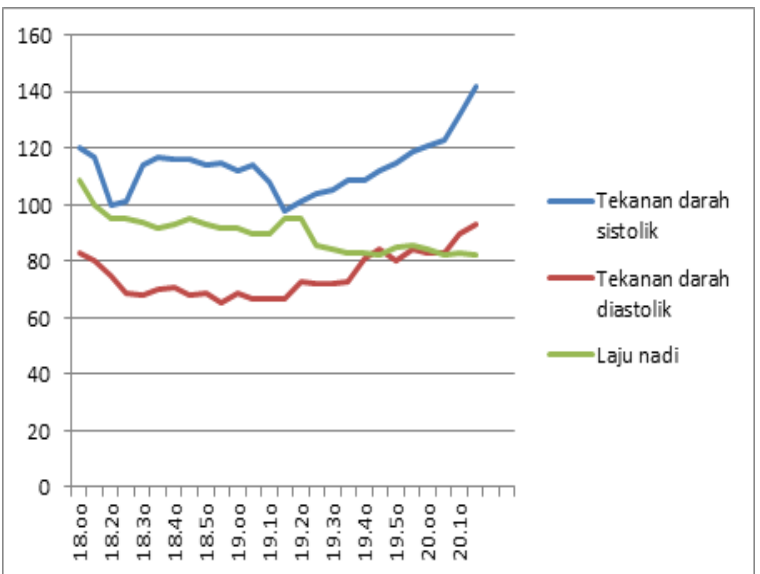

Gambar 2. Keadaan Hemodinamik Pasien saat Operasi

campuran: fentanyl $300 \mu \mathrm{g}+$ midazolam 20 $\mathrm{mg}+$ vecurronium $20 \mathrm{mg}$ dijalankan $6 \mathrm{ml} / \mathrm{jam}$. Dilakukan operasi evakuasi perdarahan, sebelum dura dibuka diberikan manitol 20\% 0,5 gr/KgBB. Untuk analgetik pascabedah diberikan morfin 9 mg dan paracetamol $1 \mathrm{gr}$ intravena. Total cairan yang masuk NS $0,9 \% 2500 \mathrm{cc}$ dan ringerasetat $500 \mathrm{cc}$, perdarahan $\pm 300 \mathrm{cc}$, jumlah urin yang keluar 600 cc. Lama operasi 2 jam dan lama pasien teranestesi 2 jam 15 menit. Tekanan darah selama operasi 99/65-135/9 $\mathrm{mmHg}$ dan laju nadi $78-108 \mathrm{x} / \mathrm{menit}$. Penilaian status neurologis pascabedah menunjukkan peningkatan dibanding sebelum pembedahan.

\section{Penatalaksanaan Pascabedah di ICU}

Pasien dipindahkan ke ruangan intensive care unit (ICU) dengan menggunakan $\mathrm{O}_{2} 10 \mathrm{~L} /$ menit melalui simple mask non-rebreathing (SMRN), setelah dilakukan ekstubasi di kamar operasi. Skor GCS 12, tekanan darah 138/91 mmHg, laju nadi $95 \mathrm{x} / \mathrm{menit}$, laju napas $12-16 \mathrm{x} / \mathrm{menit}, \mathrm{SaO}_{2}$ 100\%. Laboratorium pascabedah menunjukkan: $10,1 \mathrm{~g} / \mathrm{dL} ;$ Ht $34 \mathrm{~g} / \mathrm{dL}$; Leukosit 10500/ $\mu \mathrm{L}$; Trombosit $158 \mathrm{ribu} / \mu \mathrm{L} ;$ BUN $32 \mathrm{mg} / \mathrm{dL}$; Kreatinin 0,8 mg/dL; GDS $107 \mathrm{mg} / \mathrm{dL}$; Natrium $143 \mathrm{mmol} / \mathrm{L}$; Kalium 3,9 mmol/L. Pasien dirawat di ICU selama 2 hari, lalu dipindahkan ke ruang HCU. Pada hari ke-5 pascabedah mulai diberikan enoxaparin sodium $50 \mathrm{mg}$ Sub cutan selama 6 hari. Lalu pasien dipindahkan ke ruang rawat inap dan pulang ke rumah pada hari ke-15 perawatan. 


\begin{tabular}{ll}
\hline Transient Risk Factors & Permanent Risk Factors \\
\hline Infection & Inflammatory Diseases \\
Central nervous system & Systemic lupus erytheatosus \\
Ear, sinus, mouth, face, and neck & Behoet disease \\
Systemic infectious disease & Granulomatosis with polyangiitis (Wegener's) \\
Pregnancy and puerperium & Tromboangiitis obliterans \\
Others disorders & Inflammatory bowel disease \\
Dehydration & Sarcoidosis \\
Mechanical precipitants & Malignancy \\
Head injury & Central nervous system \\
Lumbar puncture & Solid tumuor outside central nervous system \\
Neurosurgical procedures & Hematologic \\
Jugular catheter occlusion & Hematologic condition \\
Drugs & Polycythemia, thrombocythemia \\
Oral contraoeptives & Anemia, including paroxymal nocturnal \\
Hormone replacement therapy & hemoglobinuria \\
Androgens & Central nervous system disorders \\
Asparaginase & Dural fistulae \\
Tamoxifen & Other disorders \\
Glucocoticoids & Congenital heart disease \\
\hline Gambar 3. Thyroid disease \\
\hline
\end{tabular}

Gambar 3. Klasifikasi Kondisi sementara dan Permanen meningkatkan Risiko Vena Serebral Thrombosis

\section{Pembahasan}

Cerebral venous sinus thrombosis (CVST) adalah suatu kelainan pembuluh darah otak yang sangat jarang, dengan angka kejadian $<1 \%$ dari semua kasus stroke. ${ }^{12}$ Angka kejadiaan pasti pada orang dewasa belum diketahui secara pasti, karena kurangnya laporan penelitian berbasis populasi. Namun berdasarkan data yang ada diperkirakan angka kejadian CVST sekitar 5-8 kasus/tahun di beberapa pusat pelayanan tersier. Sebuah penelitian di Kanada melaporkan angka kejadian CVST sekitar 0,67 kasus per 100.000 anak di bawah 18 tahun dan 43\% kasus yang dilaporkan terlihat pada neonatus. ${ }^{13-14}$ Puncak usia berdasarkan angka kejadian pada orang dewasa adalah pada dekade ketiga mereka dengan rasio pria:wanita 1,5-5 per tahun. Faktor risiko utama CVST pada orang dewasa dapat dikelompokkan dalam dua kelas: sementara atau permanen (Gambar 3). ${ }^{14}$ Secara topografi, kejadian CVST paling sering terjadi pada sinus sagitalis superior
(62\%) diikuti oleh sinus melintang (41-45\%) (Gambar 3). ${ }^{12}$

Diagnosis CVST masih sering terabaikan atau tertunda karena spektrum gejala klinis yang luas dan waktu kejadian sering akut. Sakit kepala adalah gejala CVST yang paling sering terjadi dan terjadi pada hampir $90 \%$ dari semua kasus. Sakit kepala mungkin timbul secara akut dan secara klinis tidak dapat dibedakan dari sakit kepala pada pasien dengan perdarahan subarachnoid. Gejala neurologis fokal (termasuk kejang fokal atau umum) jauh lebih sering terlihat pada CVST daripada pada stroke perdarahan akibat pecahnya aneurisma otak dan terjadi sekitar $40 \%$ dari semua pasien dengan angka kejadian yang lebih tinggi (76\%) pada CVST pasca melahirkan. Gejala neurologis fokal lainnya: defisit motor sentral dan sensorik, aphasia atau hemianopsia terjadi pada $40-60 \%$ dari semua kasus. Diagnosis CVST harus selalu dipertimbangkan pada pasien dengan defisit fokal yang disertai sakit kepala, kejang atau penurunan kesadaran perubahan. ${ }^{15}$ 


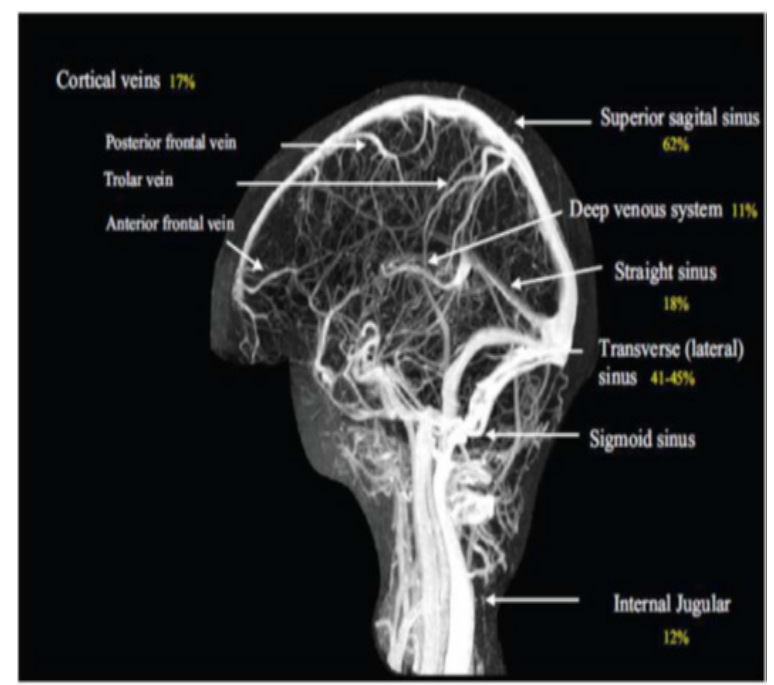

Gambar 4. Gambaran Magnetic Resonance Venography (MRV) Sistem Vena Otak dan Lokasi CVST yang paling sering. ${ }^{12}$

Sindrom tekanan tinggi intrakranial seperti sakit kepala, muntah dan penglihatan kabur karena papilloedema adalah keluhan klinis tersering pada $20-40 \%$ kasus CVST. Keadaan kesadaran stupor sampai koma ditemukan pada 15-19\% pasien dan biasanya terlihat pada kasus dengan trombosis ekstensif atau terjadi di sistem vena dalam yang melibatkan thalamic bilateral. Pasien CVST dengan keadaan seperti ini mempunyai prognosis dan hasil luaran yang sangat buruk. Oleh karena itu, pengetahuan akan patofisiologi terjadinya CVST sangatlah penting. ${ }^{12-15}$

\section{Patogenesis Cerebral Venous Sinus Thrombosis}

Patogenesis CVST tetap tidak sepenuhnya dipahami karena variabilitas yang tinggi dalam anatomi sistem vena dan kurangnya penelitian pada model hewan CVST. Namun, setidaknya ada dua mekanisme yang berbeda yang dapat berkontribusi pada gambaran klinis dari CVST: a) trombosis vena serebral atau sinus dural yang mengarah ke lesi parenkim serebral atau disfungsi; b) oklusi sinus dural yang mengakibatkan penurunan penyerapan cairan serebrospinal dan peningkatan tekanan intrakranial. (Gambar 5). ${ }^{14}$ Obstruksi struktur vena dapat menyebabkan peningkatan tekanan vena, penurunan tekanan perfusi kapiler dan peningkatan volume darah otak. Dilatasi vena otak dan peranan sistem

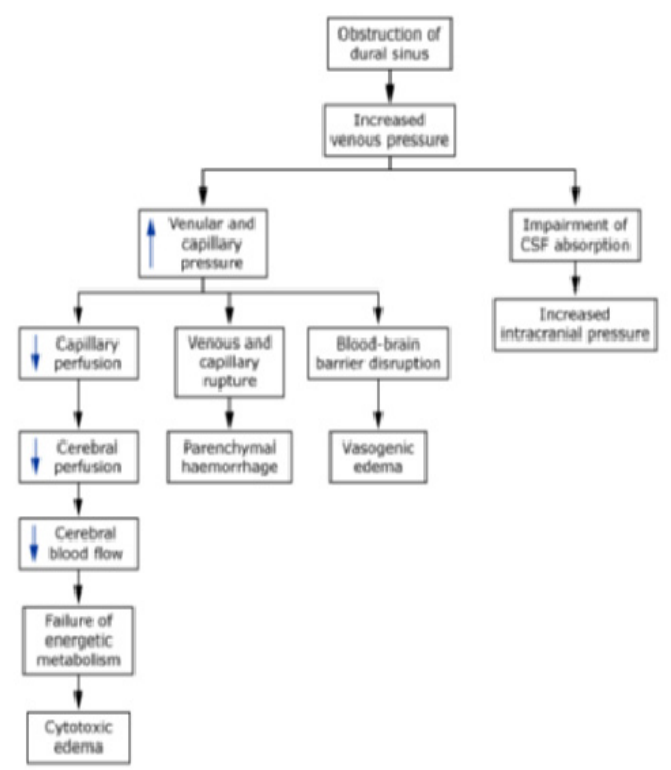

Gambar 5. Patogenesis CVST ${ }^{14}$

Dikutip dari Saposnik G, Barinagarrementeria F, Brown RD Jr, dkk. ${ }^{14}$

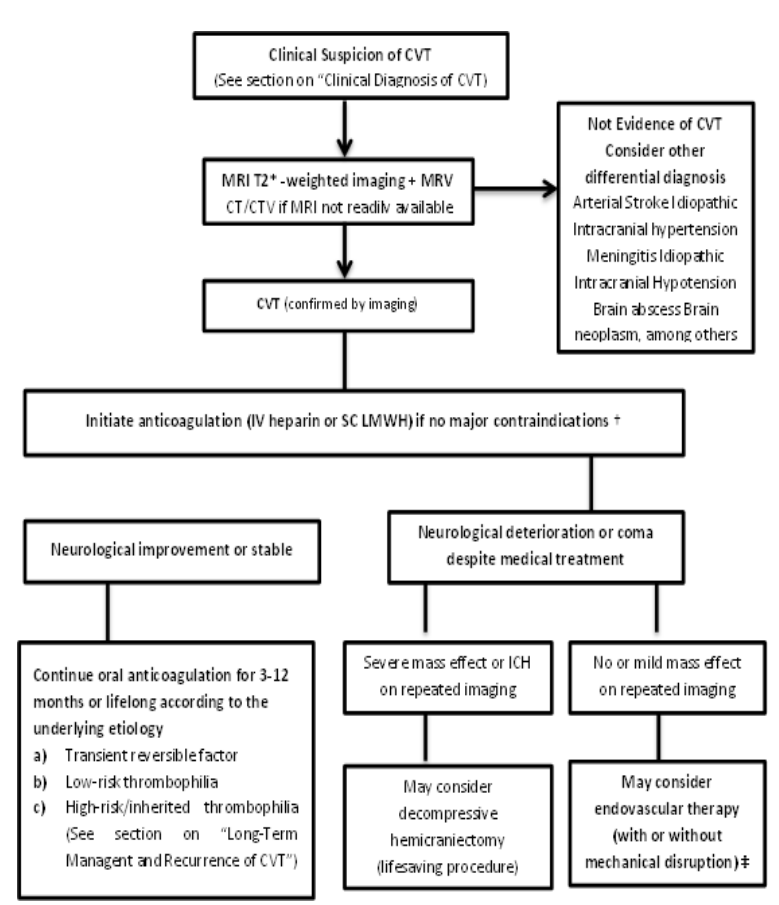

Gambar 5. Algoritma tatalaksana pasien CVST; $\uparrow$ Perdarahan intraserebral yang terjadi sebagai konsekuensi CVST bukanlah kontraindikasi untuk antikoagulan \$ Terapi endovaskular dapat dipertimbangkan pada pasien dengan absolute kontraindikasi untuk terapi antikoagulan atau kegagalan dosis terapeutik awal terapi antikoagulan. ${ }^{14}$

Dikutip dari: Saposnik G, Barinagarrementeria F, Brown RD Jr, dkk. ${ }^{14}$ 
vena kolateral memainkan peran penting dalam fase awal CVST, karena dapat mengkompensasi perubahan tekanan intrakranial. Peningkatan tekanan vena dan kapiler menyebabkan gangguan pada sawar darah otak sehingga menyebabkan edema vasogenik, karena kebocoran plasma darah ke dalam ruang interstisial. ${ }^{15}$

Karena tekanan intravena yang terus meningkat, perubahan parenkim ringan, edema otak berat dan perdarahan vena dapat terjadi karena ruptur vena atau kapiler. Tekanan intravena yang meningkat dapat menyebabkan peningkatan tekanan intravaskular dan penurunan tekanan perfusi otak. Hal ini mengakibatkan penurunan aliran darah otak dan kegagalan metabolisme energi. Hal ini mengakibatkan masuknya air intraselular kerena kegagalan pompa $\mathrm{Na}+/ \mathrm{K}+$ ATP-ase, sehingga terjadi edema sitotoksik. ${ }^{14-15}$

Alkoholik dan Cerebral Venous Sinus Thrombosis Hubungan antara konsumsi alkohol berat dengan peningkatan risiko stroke sangat erat. Hasil dari 35 penelitian meta-analisis tahun publikasi 2003 menunjukkan risiko stroke yang lebih rendah pada peminum yang mengkonsumsi alkohol $\leq$ $12 \mathrm{~g}$ alkohol per hari dibandingkan dengan orang yang bukan pecandu alkohol. Pecandu alkohol ringan memiliki risiko stroke perdarahan sebesar $17 \%$ lebih rendah dan $20 \%$ resiko stroke iskemik lebih rendah dibandingkan dengan bukan pecandu alkohol. Peminum moderat (12-23 g/ hari) juga memiliki risiko stroke iskemik $25 \%$ lebih rendah dibandingkan dengan bukan pecandu alkohol. ${ }^{9}$

Penelitian yang dipublikasikan tahun 2010 menunjukkan bahwa angka kejadian kecacatan dan kematian meningkat pada pecandu alkohol. Penelitian ini mempunyai 'benang merah'/ hubungan dengan penelitian yang dipublikasikan tahun 2003 tersebut bahwa terdapat korelasi antara pecandu alkohol dengan stroke perdarahan. ${ }^{9-10}$ Penelitian yang dipublikasikan tahun 2013 masih belum bisa membuktikan secara pasti mengenai hubungan antara konsumsi alkohol ringan dengan stroke perdarahan, sehingga masih diperlukan penelitian lebih lanjut dalam skala besar. ${ }^{10}$ Patofisiologi konsumsi alkohol yang menyebabkan stroke belum jelas, diduga berbagai mekanisme seperti gangguan induksi irama jantung dan kelainan gerak dinding jantung, hipertensi, peningkatan agregasi platelet serta aktivasi kaskade pembekuan. Hal-hal ini yang menyebabkan aliran darah otak menurun kerena gangguan stimulasi kontraksi otot polos otak. ${ }^{9-10}$ Pada pasien dengan konsumsi alkohol berat tanpa disertai faktor predisposisi lain, mekanisme CVST mungkin dapat dijelaskan lebih spesifik. Beberapa menelitian menunjukkan bahwa hal ini terjadi karena dehidrasi dan hiperviskositas darah, sehingga terjadi trombus. ${ }^{9-10}$ Kondisi predisposisi yang biasa untuk CVST adalah penggunaan kontrasepsi oral, kehamilan, pasca melahirkan, gangguan pada faktor waktu prothrombotin, penyakit infeksi (khususnya telinga-hidung-tenggorokan, susunan saraf pusat), gangguan sistem saraf pusat, kanker, vaskulitis dan penyakit sistemik lainnya. ${ }^{1-14}$ Manifestasi klinis CVST pada pasien dengan konsumsi alkohol berat yang tidak spesifik merupakan tantangan diagnostik untuk para ahli penyakit saraf dan bedah saraf. Gejala seperti sakit kepala, mual, muntah dan kantuk sering terjadi pada veisalgia (istilah medis untuk mabuk) dan CVST.9-10 Hal ini menyebabkan diagnosis CVST sering terlewatkan pada pasien alkoholik. Para ahli harus lebih meningkatkan kecurigaan pada pasien pecandu alkohol ke arah diagnosis CVST, bila timbulnya tanda dan gejala klinis baru, seperti: penurunan kesadaran, kejang, gangguan sensorik, defisit neurologis fokal, atau paresis. ${ }^{9-10}$

\section{Pemeriksaan Penunjang pada Pasien CVST}

Pasien dengan dugaan CVST, pemeriksaan darah rutin terdiri dari pemeriksaan darah lengkap, panel kimia, prothrombin time (PT), dan activated partial thromboplastin time (APTT) harus dilakukan. Skrining untuk kondisi kelainan hematolgik pada pasien dengan resiko tinggi permanen CVST (Tabel 1) dianjurkan dilakukan sejak pemeriksaan klinis awal. ${ }^{14}$ Nilai normal D-dimer sesuai dengan immunoassay sensitif atau enzyme-linked immunosorbent assay (ELISA) menunjukkan kemungkinan probabilitas CVST sangat kecil. Jika ada kecurigaan secara gejala klinis CVST yang kuat, nilai D-dimer normal seharusnya tidak menjadi tolak ukur untuk 
dilakukan pemerikan pencitraan otak. ${ }^{14-15}$

Computed tomography scan (CT-scan) dan MRI adalah pemeriksaan penunjang yang sangat berguna dalam membuat diagnosis CVST awal dan spesifik. Pemeriksaan CT-scan menunjukkan hiperdensitas, sedangkan pada MRI tampak hiperintensitas pada urutan $\mathrm{T} 1 \mathrm{~W}$ pada sinus trombosis akut. ${ }^{4,7}$ Magnetic resonance venography (MRV) adalah pemeriksaan penunjang noninvasive pilihan untuk mendiagnosis CVST. Pada keadaan gejala klinis akut, MRV nonkontras cukup akurat untuk diagnosis CVST. Kontras MRV diperlukan untuk mengatasi beberapa keterbatasan diagnostic MRV nonkontras yang mungkin timbul pada kasus varian anatomis, variabilitas sinyal trombus dan artefak pencitraan. . $^{4,8,11-14}$

\section{Tatalaksana Pasien CVST}

Target pencapaian utama pada pasien CVST adalah untuk rekanalisasi penyumbatan, menjaga venous return, mengurangi risiko hipertensi vena, infark serebral dan emboli paru. ${ }^{15}$ Tatalaksana CVST (Gambar 5). Algoritma ini tidak komprehensif, atau berlaku untuk semua skenario klinis dan pengelolaan pasien harus disesuaikan dengan keadaan klinis. Terapi antikoagulan awal (TA) memiliki 3 tujuan dalam CVST: a) untuk mencegah pertumbuhan trombus, b) untuk memfasilitasi rekanalisasi, dan c) mencegah deep vein thrombosis (DVT) atau emboli paru. ${ }^{14}$ Ada kontroversi dalam pertimbangan untuk rekomendasi mengenai terapi antikoagulan, karena infark serebral yang disertai perdarahan intrakranial biasanya ada pada saat diagnosis CVST, sehingga hal ini menjadi dilemma dalam pengelolaan pasien. ${ }^{11-16}$

Sejumlah penelitian observasional baik prospektif maupun retrospektif telah banyak dilakukan. Tidak semua penelitian dilaporkan secara khusus mengenai hasil pengelolaan pasien dengan antikoagulan, karena sebagian besar pasien di kebanyakan penelitian diterapi dengan unfractionated heparin (UFH) intravena atau heparin dengan berat molekul rendah (lowmolecular-wieght-heparin/LMWH) pada saat diagnosis dan menggunakan antagonis vitamin $\mathrm{K}$ pada akhirnya. ${ }^{14-16}$ Angka kematian pada CVST $<$ $10 \%$, tetapi seringnya penyebab kematian pasien adalah penyakit yang mendasarinya, bukan kerena perdarahan intrakranial atau CVST. Hasil luaran fungsi neurologis pasien pada umumnya bagus, angka kecacatan pada kasus CVST juga kecil. Sebuah penelitian retrospektif terhadap 102 pasien dengan CVST dan 43 pasien disertai perdarahan intrakranial. Di antara 27 pasien CVST yang disertai perdarahan intrakranial (63\%) yang diterapi dengan heparin intravena dosis anjuran, 4 pasien meninggal (15\%), dan 14 pasien $(52 \%)$ sembuh total. Dari 13 pasien yang tidak diterapi heparin, angka kematian lebih tinggi (69\%) dengan perbaikan hasil luaran fungsi neurologis yang lebih rendah (hanya 3 pasien yang sembuh total). ${ }^{12-14}$

Studi terbesar sejauh ini adalah International Study on Cerebral Vein and Dural Sinus Thrombosis (ISCVST), yang melibatkan 624 pasien di 89 pusat di 21 negara. Hampir semua pasien diterapi dengan antikoagulan sejak awal. Hasil dari ISCVST melaporkan bahwa angka kematian 8,3\% selama 16 bulan; 79\% mengalami pemulihan yang sempurna (dinilai dengan modified-Rankin Scale (mRS) 0 sampai 1), 10,4\% memiliki kecacatan ringan sampai sedang (skor mRS 2-3) dan $2,2 \%$ tetap sangat cacat (skor mRS $4-5$ ). ${ }^{10}$ Data dari penelitian observasional menunjukkan resiko terjadinya komplikasi perdarahan intrakranial setelah terapi antikoagulan $<5,4 \%{ }^{14}$ Penelitian lain melibatkan 57 wanita (dengan CVST pasca melahirkan yang dikonfirmasi hanya dengan CT-scan) dengan kriteria eksklusi pasien yang mengalami pendarahan intrakranial di CT-scan. Tatalaksana pasien dengan heparin 5000 IU per 6 jam, dosis disesuaikan dengan pemeriksaan PT yang tidak meningkat 1,5 dari baseline setidaknya 30 hari setelah persalinan. Tiga pasien dalam kelompok kontrol meninggal atau mengalami kecacatan dibandingkan dengan kelompok terapi heparin. Dalam situasi khusus CVST dengan pendarahan intrakranial dihubungkan dengan hasil luaran yang buruk dengan atau tanpa terapi heparin. ${ }^{12-16}$ Pada kasus yang kami tangani juga tidak sepenuhnya sesuai dengan algoritma tatalaksana yang sudah direkomendasikan. Hal ini disesuaikan dengan 
kondisiklinis pasien saat tiba di rumah sakit. Pasien datang dengan GCS 9-10 disertai perdarahan intrakranial, ada riwayat muntah sebelumnya dan defisit neurologis. Pada pemeriksaan CT-scan terdapat perdarahan intrakranial disertai dengan edema lokal dan sedikit pergeseran midline shift. Hal ini menunjukkan bahwa sudah kemungkinan sudah terjadi peningkatan tekanan intrakranial. Ahli bedah saraf memutuskan untuk melakukan dekompresi evakuasi perdarahan terlebih dahulu sebagai tindakan penyelamatan jiwa.

Tatalaksana anestesi pada prinsipnya sama dengan dasar-dasar neuroanestesi dan pengelolaan pasien yang dilakukan tindakan operasi dekompresi evakuasi perdarahan. Untuk induksi kami menggunakan fentanyl, propofol dan vecuronium. Obat-obatan anestesi rumatan yang digunakan: fentanyl, midazolam dan vecuronium yang dicampur dalam satu syringe pump. Selain itu, kami menggunakan isoflurane, $\mathrm{O}_{2}$ dan udara. Pemberian fentanyl pada aliran darah otak sulit dijelaskan dengan tepat kerena data eksperimen yang berbeda. ${ }^{17}$ Fentanyl termasuk golongan opioid, yang dapat memberikan efek sedasi, analgesia dan menyebabkan terjadinya penurunan pelepasan neurotransmitter otak, sehingga autoregulasi, reaktivitas terhadap $\mathrm{CO}_{2}$ dan hemodinamik tetap stabil. Akan tetapi, dosis kecil narkotik memberikan sedikit pengaruh pada aliran darah otak dan $\mathrm{CMRO}_{2}$, sedangkan dosis besar menurunkan aliran darah otak dan $\mathrm{CMRO}_{2} \cdot{ }^{17-19}$

Propofol mempunyai efek terhadap tekanan perfusi otak disebabkan oleh menurunnya tekanan darah, tetapi efek hemodinamik yang tidak menguntungkan ini dapat dicegah dengan menghindari efek konsentrasi puncak, hal ini yang menjadi pertimbangan kami untuk menggunakan midazolam. Midazolam menyebabkan penurunan aliran darah otak dan $\mathrm{CMRO}_{2}$ secara paralel sampai $40 \%$. Dibandingkan dengan pentotal, efek penekanan metabolisme otak lebih sedikit. Pemberian midazolam dosis kecil pun tidak terlalu mempengaruhi tekanan intrakranial. Keuntungan vecuronium adalah dapat menjaga hemodinamik tetap stabil, walaupun dalam jumlah dosis besar. Bradikardia pada saat induksi anestesi dapat terjadi ketika vecuronium dikombinasi dengan golongan narkotik dalam dosis besar. Vecuronium tidak mengubah tekanan intrakranial atau aliran cairan serebrospinal. Halhal inilah yang menjadikan vecuronium sangat popular digunakan dalam neuroanestesi. ${ }^{17-19}$ Sebagai analgetik pascabedah kami mengunakan morfin dan paracetamol. Morfin merupakan analgetik kuat dan tidak mempengaruhi sistem saraf pusat. Morfin biasa digunakan sebagai analgetik pascabedah saraf. Hipotensi yang terjadi setelah pemberian morfin disebabkan karena pelepasan dari histamin. Paracetamol digunakan sebagai analgetik perifer, karena tidak mempengaruhi sistem saraf pusat. Selain itu paracetamol mempunyai efek antipiretik dan antiinflamasi yang sangat bermanfaat pada pasien pascabedah saraf. ${ }^{19}$

Pemberian cairan rehidrasi dan rumatan selama pembedahan sesuai dengan aturan umum pada pasien bedah saraf lainnya yaitu menghindari penggunaan cairan yang hiperosmolar dan cairan yang mengandung glukosa. Pemberian $\mathrm{NaCL}$ 0,9\%: RL, setiap pemberian NaCL $0,9 \%$ sebanyak 3 botol, diberikan RL 1 botol (3:1). Jumlah cairan pemeliharaan $1-1,5 \mathrm{ml} / \mathrm{KgBB} / \mathrm{jam}$ atau diganti $2 / 3$ dari jumlah diuresis. Pemberian manitol dosis kecil $0,25-0,5 \mathrm{mg} / \mathrm{KgBB}$ pada kasus ini dinilai masih dalam batas aman sebagai terapi edema lokal dengan memperhatikan secara ketat volume intravaskular. ${ }^{18}$ Untuk pemberian terapi antikoagulan, kami tetap memberikan pascabedah. Hal ini dengan pertimbangan untuk mecegah terjadinya komplikasi CVST lainnya. Kami menggunakan UFH 50 mg subcutan selama 6 hari, dengan target pemeriksaan PT dan INR tidak terjadi kenaikan $>1,5-2 \mathrm{x}$ dari baseline. 16 Pada pemeriksaan akhir PT 18,4 detik dan INR 1,5.

\section{Simpulan}

Angka kejadian CVST pada seorang pasien alkoholik cukup tinggi. Hal ini disebabkan karena terjadinya dehidrasi yang merubah aliran darah, struktur dinding vena dan komposisi dari darah. Algoritma tatalaksana pasien CVST terkadang harus disesuaikan dengan kondisi klinis pasien saat tiba di rumah sakit. Operasi 
dekompresi evakuasi perdarahan dilakukan bila keadaan kondisi klinis pasien mengancam jiwanya. Pemberian LWMH tetap diberikan selama pada pemeriksaan penunjang darah tidak terjadi peningkatan yang bermakna. Penelitian menunjukkan bahwa penggunaan heparin pada pasien CVST bersamaan dengan perdarahan intrakranial belum terbukti dapat meningkatkan ukuran perdarahan. CVST berhubungan dengan perdarahan intracranial bukan karena pecahnya pembuluh darah.

\section{Daftar Pustaka}

1. Algahtani HA, Aldarmahi AA. Cerebral venous sinus thrombosis. Neurosciences (Riyadh) 2014; 19: 11-16.

2. Bousser MG, Ferro JM. Cerebral venous thrombosis: an update. Lancet Neurol 2007; 6: $162-170$.

3. Stam J. Thrombosis of the cerebral veins and sinuses. N Engl J Med 2005; 352: 1791-1798.

4. Fischer C, Goldstein J, Edlow J. Cerebral venous sinus thrombosis in the emergency department: retrospective analysis of 17 cases and review of the literature. J Emerg Med 2010; 38: 140-147.

5. Guenther G, Arauz A. Cerebral venous thrombosis: a diagnostic and treatment update. Neurologia 2011; 26: 488-498.

6. Oppenheim C, Domigo V, Gauvrit JY, Lamy C, Mackowiak-Cordoliani MA, Pruvo JP, et al. Subarachnoid hemorrhage as the initial presentation of dural sinus thrombosis. AJNR Am J Neuroradiol 2005; 26: 614-617.

7. Boukobza M, Crassard I, Bousser MG, Chabriat $H$. Radiological findings in cerebral venous thrombosis presenting as subarachnoid hemorrhage: a series of 22 cases. Neuroradiology 2016; 58: 11-16.

8. Gu J, Li B, Chen J, Hong J, Liu H, Wang $\mathrm{S}$. Cerebral venous thrombosis and acute subarachnoid hemorrhage: a retrospective study on diagnosis, treatment prognosis of 11 patients. Biomedres 2017; 28 (19): 8496-50.

9. Singh H, Paulomi T, Ray S, Gupta V. A rare presentation of acute alcohol intoxication, subarachnoid haemorrhage and cortical venous thrombosis. JNeurol Res 2012;2:62-4.

10. Canhao P, Bousseur MG, Barinagarrementeria F, Stam J,Ferro JM; The ISCVT Collaborators. Predisposing conditions for cerebral vein and dural sinus thrombosis. Available from: http://www.iscvt.com/index.htm. [Last cited on 2013 Dec 20].

11. Ntaios G, Bornstein NM, Caso V, Christensen H, De Keyser D, Diener HC, et al. The European Stroke Organisation Guidelines: a standard operating procedure. Int J Stroke 2015; 10: 128-135.

12. Ferro JM, BousserM.-G., Canhão P, Coutinho JM, Cassard I, Dentali F, et al. European Stroke Organization guideline for the diagnosis and treatment of cerebral venous thrombosis - endorsed by the European Academy of Neurology. European Stroke Journal 2017; 2 (3): 195-221.

13. Einhäupl K, Stam J, Bousser MG, De Bruijn SF, Ferro JM, Martineli I, Mashur F. EFNS guideline on the treatment of cerebral venous and sinus thrombosis in adult patients. Eur J Neurol 2010; 17: 1229-1235.

14. Saposnik G, Barinagarrementeria F, Brown RD Jr, Busnell CD, Cucchiara B, Cushman $\mathrm{M}$, et al. Diagnosis and management of cerebral venous thrombosis: a statement for healthcare professionals from the American Heart Association/American Stroke Association. Stroke 2011; 42: 1158-92.

15. Coutinho JM. Cerebral venous Thrombosis. J Thromb Haemost 2015; 13 (1): S238-S44.

16. Coutinho JM, Middeldrop S, Stam J. Advaces in the treatment of cerebral venous 
thrombosis. Curr Treat Options Neuro I 2014; 16: 299-310.

17. Bisri T. Penanganan neuroanesthesia dan critical care: cedera otak traumatik. Bandung: Universitas Padjadjaran; 2012.

18. Saleh SC. Cairan untuk tindakan bedah otak. Dalam: Saleh SC, editor. Sinopsis
Neuroanestesia Klinik, edisi ke-2, Surabaya: Zifatama; 2013, 49-60.

19. Wlody DJ, Weems L. Anesthesia for neurosurgery in the pregnant patient. Dalam: Cottrell JE, Young WL, editor. Cottrell and Young's Neuroanesthesia, edisi ke-5, Philadelphia: Mosby; 2010, 416-24. 